Roger Williams University

DOCS@RWU

Population Maintenance of the Scyphozoan Cyanea sp. Settled Planulae and the Distribution of Medusae in the Niantic River, Connecticut, USA

Sean Colin

RogerWilliams University, scolin@rwu.edu

Patricia Krener

University of Connecticut

Follow this and additional works at: https://docs.rwu.edu/fcas_fp

Part of the Biology Commons

Recommended Citation

Colin, S. P. and Kremer, P. 2002. Population maintenance of the scyphozoan Cyanea sp. settled planula and the distribution of medusae in the Niantic River, CT, USA. Estuaries. 25: 70-75.

This Article is brought to you for free and open access by the Arts and Sciences at DOCS@RWU. It has been accepted for inclusion in Arts \& Sciences Faculty Publications by an authorized administrator of DOCS@RWU. For more information, please contact mwu@rwu.edu. 


\title{
Population Maintenance of the Scyphozoan Cyanea sp. Settled Planulae and the Distribution of Medusae in the Niantic River,
} Connecticut, USA

\author{
SEAN P. Colin* and Patricia Kremer \\ Marine Sciences Department, University of Connecticut, Groton, Connecticut 06340
}

\begin{abstract}
Scyphozoan jellyfish are seasonally conspicuous in coastal waters, but relatively little is known about the factors that control their distribution and population dynamics. Cyanea sp. is a seasonally abundant medusa in the Niantic River, Connecticut, U.S. and appears to maintain a population entirely within the estuary. To better understand the factors controlling their occurrence, we examined the temporal and spatial distribution of settled scyphistomae in relation to that of the medusae. Planula settlement patterns mirrored the presence of mature female medusae. The planulae settled primarily near the bottom. After settlement, planulacysts and polyps on the settlement plates were out competed by large barnacle and ascidian larvae, resulting in a sharp decline in cyst and polyp abundance. This stage-specific mortality may represent a population bottleneck in the life cycle of scyphozoans.
\end{abstract}

\section{Introduction}

Scyphozoan jellyfish can be a dominant pelagic carnivore in coastal marine systems (Huntley and Hobson 1978; Möller 1979; Feigenbaum and Kelly 1984; Purcell 1992; Cowen and Houde 1993; Behrends and Schneider 1995) and may be able to restructure the food webs they periodically dominate (Verity and Smetacek 1996). Efficient prey capturing abilities and high abundances contribute to their trophic success. While prey selection (Fancett 1988; Båmstedt et al. 1994; Sullivan et al. 1994; Purcell 1997; Purcell and Sturdevant 2001) and feeding mechanisms (Costello and Colin 1994, 1995; Ford et al. 1997) of scyphomedusae have been well studied, the factors influencing their seasonal abundance are not understood well. As the scyphozoan life cycle involves both a conspicuous pelagic stage and a less conspicuous benthic stage, an understanding of the seasonal abundance of medusae requires an understanding of the benthic stage as well.

Jellyfish recruitment is determined by the success of each part of their life cycle. This includes the ability of the planulae to settle and metamorphose, the scyphistomae to survive and strobilate, and the ephyrae to survive and grow into adults. Scyphozoan life history is further complicated because the polyps or planulae may form cysts when conditions are unfavorable and then later excyst to form polyps (Cargo and Schultz 1966, 1967; Cargo and Rabenold 1980; Brewer and Feingold 1991).

\footnotetext{
* Corresponding author; tele: 860/405-9097; e-mail: sean. colin@uconn.edu.

The attached benthic polyp stage determines the seed stocks of larval medusae produced by asexual reproduction. The distribution, abundance, and survival of the scyphistomae is key to understanding the distribution and abundance of the medusae.

A few studies have focused on factors that influence settlement of planulae (Brewer 1978, 1984; Keen 1987; Gröndahl 1988a,b, 1989; Dolmer and Svane 1993; Svane and Dolmer 1995) and stimulate strobilation (Cargo and Shultz 1966; Loeb 1972; Gröndahl and Hernroth 1987; Brewer and Feingold 1991; Purcell et al. 1999). However, there has been little effort to examine the influence of the medusae on the abundance and distribution of the scyphistomae. If we expect to be able to determine where blooms of jellyfish will occur and how large they will be, we need to identify indicators that will provide predictive information about the distribution of the scyphistomae that seed the stock of medusae.

The only other studies that have related the pelagic and benthic life stages of scyphozoan jellyfish were done in the site of the present study, Niantic River, Connecticut (Brewer 1991; Brewer and Feingold 1991). These studies found that the appearance of newly settled planulae coincided in time with the appearance of gravid females. In this study we extend this work to include both the distribution and quantitative abundance of medusae and newly settled planulae.

The goal of the present study was to examine, in situ, some of the factors that influence the abundance and distribution of the benthic stage of the 
scyphozoan life cycle to understand better the factors controlling the medusan population dynamics and distribution. Our approach was to compare the abundance and distribution of the medusan stage of Cyanea sp., a resident scyphozoan, in the Niantic River to that of newly settled benthic cysts and polyps. We examined the rate of settlement and the survival of the newly settled cysts and polyps throughout the season.

\section{Materials and Methods}

Sampling for medusae took place in the Niantic River, Connecticut, U.S. $\left(41^{\circ} 19^{\prime} 31^{\prime \prime} \mathrm{N}, 72^{\circ} 11^{\prime} 37^{\prime \prime} \mathrm{W}\right)$ from April 7 to July 26, 1998. During this sampling period surface water temperatures increased from $8^{\circ} \mathrm{C}$ in April to $25^{\circ} \mathrm{C}$ in July. The Niantic River is an ideal location as it has been studied extensively in the past (Marshall 1962; Brewer 1989, 1991; Brewer and Feingold 1991; NUSCo 1998) and because of its hydrography. It is a confined estuary with a relatively small input of freshwater at the northernmost tips (freshwater inflow is about $3 \%$ of tidal prism, mean depth at MLW $=4 \mathrm{~m}$ ) and highly restricted exchange with the outside bay waters (Fig. 1). There is only a small vertical salinity gradient, with the salinities at the surface varying from 21.5 to 25 psu while at the bottom the salinities varied from 23 to $27 \mathrm{psu}$. The residence time is estimated to be $25 \mathrm{~d}$ (Kollmeyer and McGill 1972). As a result of the hydrography, inside the estuary there appears to be a closed population of Cyanea sp. with an apparent absence of exchange with populations of Cyanea spp. outside the estuary (Brewer 1989).

Four tow sites were sampled for medusae (Fig. 1). Settlement plates were deployed from docks in seven locations to measure the settlement of planulae near the tow sites and at various other places throughout the estuary. Oblique plankton tows were taken every one to two weeks between 1000 and 1200 throughout the sampling period except for Station 1 where sampling did not start until May 21 (Fig. 2). The net $(0.5 \mathrm{~m}$ diameter, $202 \mu \mathrm{m}$ mesh) was towed at 0.5 to 1 knot. The sample volume was measured using an Oceanics flow meter attached to the plankton net and ranged between 10 to $55 \mathrm{~m}^{3}$. Single tows were taken at each site from April 7 to June 6, then duplicate tows were taken at each site. Medusae were gently transferred to 20 liter buckets filled with ambient sea water and taken immediately to the laboratory for analysis. Live medusae were counted and measured within $2 \mathrm{~h}$ of sampling. Medusae with bell diameters less than $10 \mathrm{~mm}$ were categorized as ephyrae while those with bell diameters greater than 70 $\mathrm{mm}$, when relaxed but suspended completely in water, were considered to be adults. Our observa-

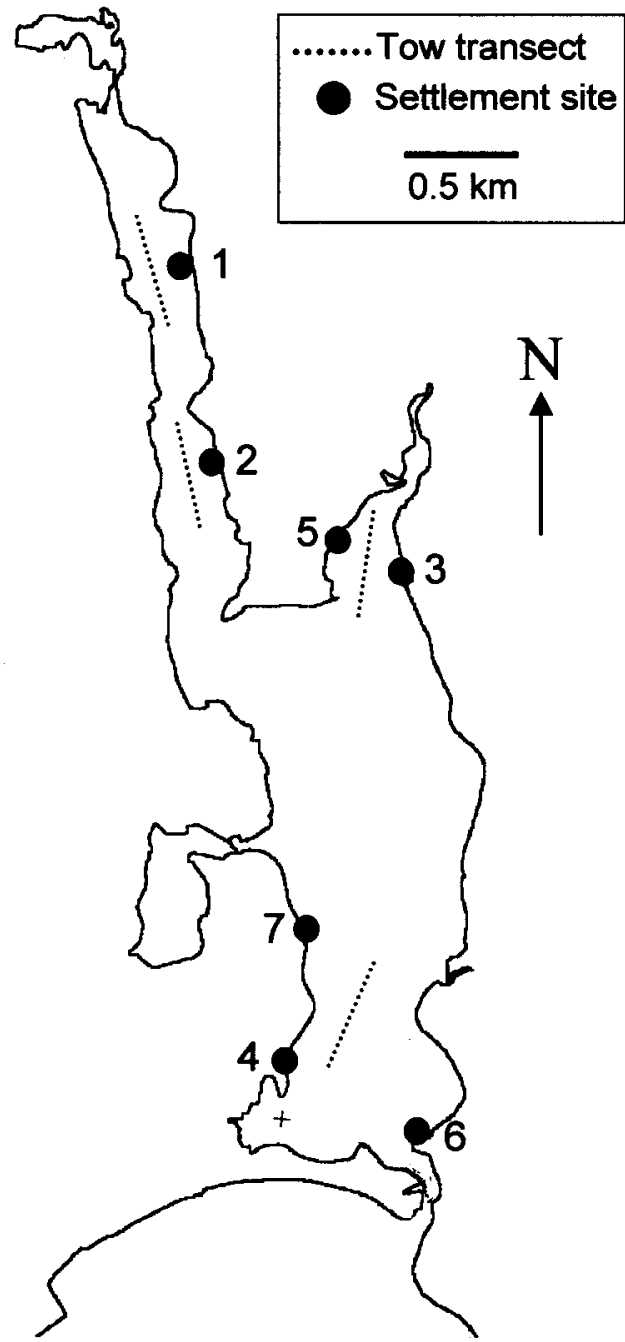

Fig. 1. Map of the study site, Niantic River, Connecticut (+ is located at $41^{\circ} 20^{\prime} \mathrm{N}, 72^{\circ} 11^{\prime} \mathrm{W}$ ). Dashed lines represent plankton tow sites and filled circles locate docks from which settlement plates were deployed.

tions of the size at which female medusae became sexually mature agreed with previous observations of the same Cyanea sp. population (Brewer 1989, 1991).

In order to measure the density of settled planulae, settlement plates $(10 \times 10 \mathrm{~cm}$ of roughened PVC) were deployed at 7 sites throughout the river. Special settlement rigs were made that suspended the plates at known distances from the bottom (Osman and Whitlatch 1995). Roughened PVC was used because it is known to be a good substrate for settlement of other benthic organisms (Brewer 1984). Due to the planulae's preference to settle on the underside of objects, the plates were suspended upside down (Brewer 1978, 1984; Svane and Dolmer 1995). Settlement plates were placed 


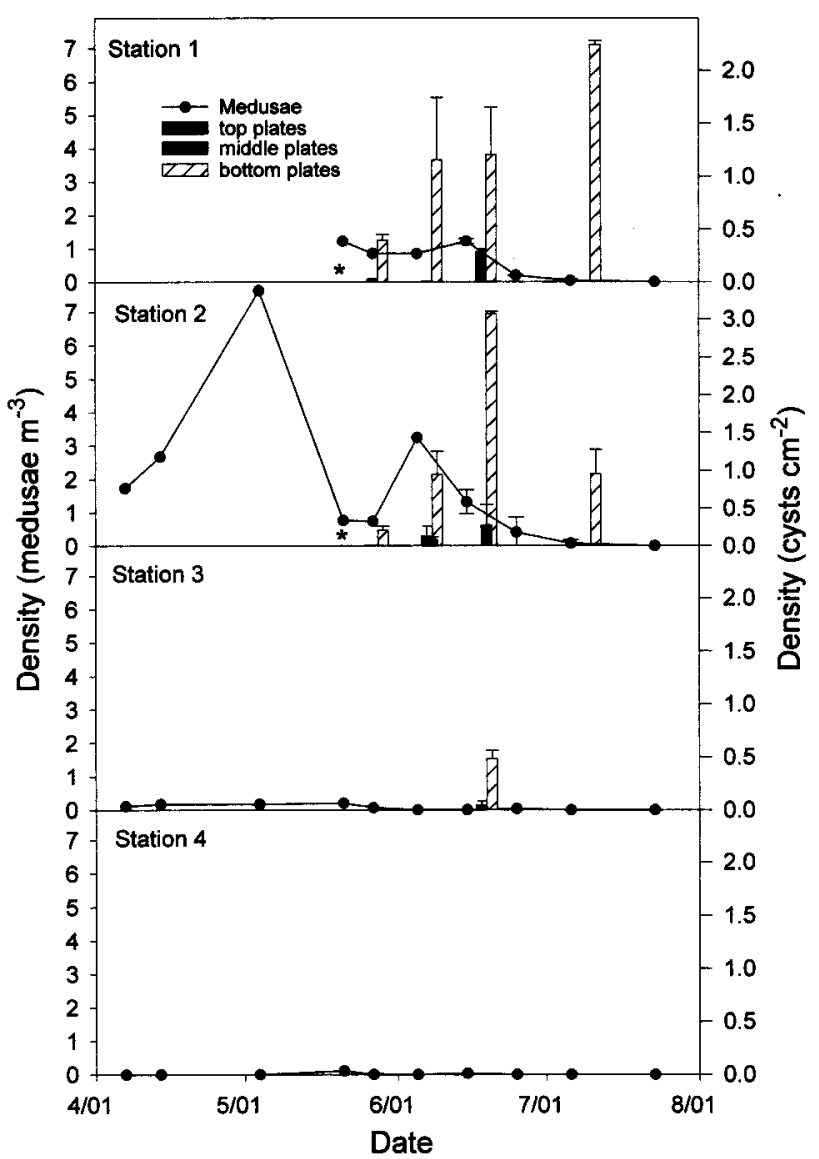

Fig. 2. Abundance of Cyanea sp. medusae (line) in the water column and total number of newly settled planulacysts (bars) on settlement plates (total plate area $=100 \mathrm{~cm}^{2}$ ) at four stations in the Niantic River. At Stations 1 and 3, settled planulae were sampled at two depths from the bottom $(20 \mathrm{~cm}$, hatched; 70 $\mathrm{cm}$, black). At Station 2 cysts were sampled at three depths from the bottom ( $20 \mathrm{~cm}$, hatched; $70 \mathrm{~cm}$ gray, $120 \mathrm{~cm}$ black). These were the only stations where either medusae or cysts were found. Error bars represent standard errors for tows taken after June 6. Asterisk (*) shows the date that plates were sampled but there were no cysts present at Stations 1 and 2.

at $0.5 \mathrm{~m}$ interval depths with the lowest plates 20 $\mathrm{cm}$ from the bottom. The number of depths sampled at each site varied depending on the water depth at each of the sites. Three depths $(20,70$, and $120 \mathrm{~cm}$ from the bottom) were sampled at Stations 2 and 6 , two depths $(20$ and $70 \mathrm{~cm}$ from the bottom) at Stations 1,3 , and 5 , and one depth (20 cm from the bottom) at Stations 4 and 7. At each depth, duplicate plates were deployed except for Station 1 where quadruplicate plates were deployed. Plates were first set out on May 15, 1998 and examined each subsequent week. Each time these plates were examined, new plates were deployed at the sample sites. Great care was taken to ensure that the plates remained as undisturbed as possible throughout the analysis. Special transfer containers were made that secured the plates in ambient seawater within coolers for transport and examination. Throughout the process, the plates were immersed in seawater with the exception of the brief period $(<30 \mathrm{~s})$ during which the plates were transferred from the settlement rig to the transport cooler. The plates were taken to the Environmental Laboratory of Millstone Nuclear Power Plant ( $\sim 1$ mile from the Niantic River), where they were examined with a microscope and all of the cysts and polyps present were counted and recorded on VHS video using a Pulnix camera attached to an Olympus Microscope. After the analysis, the old plates were immediately returned to the sample sites and re-deployed along with new plates.

\section{Results}

The study encompassed the period of seasonal growth and decline of the medusan population in the Niantic River (Fig. 2). At Station 2 the population increase of medusae was measured from the beginning of April until the beginning of May. Densities steadily decreased until the disappearance of Cyanea sp. as medusae in the beginning of July.

Cyanea sp. in the Niantic River are found in the northwest arm of the estuary (Stations 1 and 2; Fig. 2) with a significantly greater abundance (ANOVA; $p<0.001)$. Medusae were rarely observed at other sites. The distribution of newly settled planulacysts closely followed that of the medusae, with cyst densities significantly greater at Stations 1 and 2 than the rest of the river (ANOVA; $p<0.001$ ). During sampling, no cysts were found at Stations 4, 5, 6, and 7 . At Station 3 cysts were observed only on June 19.

Once settled, the planulae did not appear to develop immediately. Less than $10 \%$ of the observed planulacysts on the plates excysted to form fourtentacle polyps. Only one ten-tentacle polyp was observed during this study.

A comparison between the appearance of newly settled planulacysts and the size of medusae in the water column indicates that cysts did not appear until after the appearance of mature adults in the water column (Fig. 3). Sexually mature medusae were present as early as April 14 but they constituted less than $30 \%$ of the population until May 27 when there was a-sharp decrease in ephyrae. Adult abundances at Station 2 peaked in early June with densities of 1.2 medusae $\mathrm{m}^{-3}$ and 0.9 medusae $\mathrm{m}^{-3}$ on June 5 and 15 , respectively. This peak in abundances of sexually mature medusae (diameter $>70 \mathrm{~mm}$ ) coincided with the maximum settlement of planulae on the plates (Fig. 3).

Settlement plates from Stations 1 and 2 were in- 


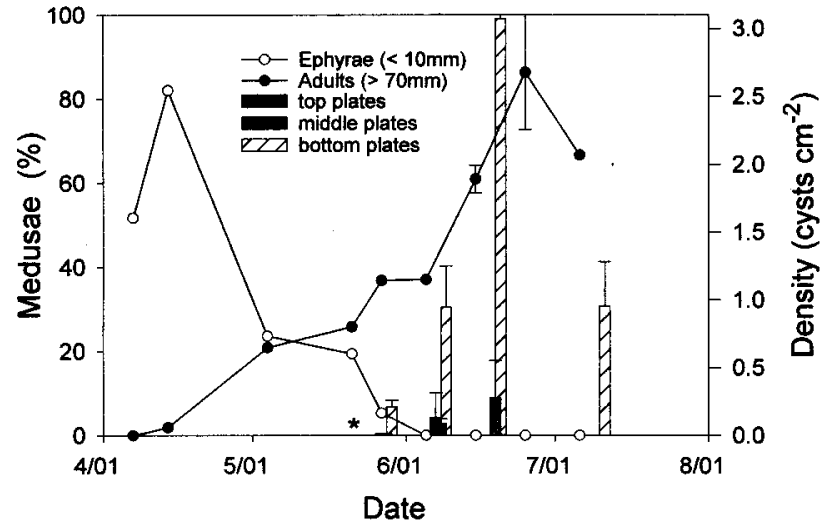

Fig. 3. Abundance of different life stages of Cyanea sp. medusae (ephyrae, open circle; adult, closed circle) in relation to the abundance of planulacysts (bars) at different depths from the bottom (20 cm, hatched; $70 \mathrm{~cm}$, gray; $120 \mathrm{~cm}$, black) at Station 2. Error bars represent standard errors. Asterisk (*) shows the date that plates were sampled but there were no cysts present.

undated with newly settled planulacysts throughout the month of June. Settlement of new planulae was much greater on the plates nearest the bottom (ANOVA; $\mathrm{p}<0.001$; Fig. 2). At all of the stations, cysts were much less abundant on plates at 70 or $120 \mathrm{~cm}$ off the bottom (e.g., Station 2; Fig. 3).

In order to assess population maintenance of the newly settled planulae, plates deployed on May 15 were replaced immediately after analysis and reanalyzed each subsequent sampling date. High densities of planulacysts were observed on these plates on May 28. Cyst abundances were reduced to zero on these same plates by June 9 at Station 2 and June 18 at Station 1 (Fig. 4). Plates deployed on May 28 were also replaced immediately after analysis and reanalyzed each subsequent sampling date. Likewise after initial settlement of planulae was observed on June 9 , cyst abundances were reduced to zero on these plates the subsequent week (data not shown). This disappearance of planulacysts coincided with heavy recruitment of barnacles and ascidians on the older plates. As soon as the plates were covered with other benthic organisms, newly settled planula densities decreased substantially. Additionally, this disappearance of cysts on older plates had occurred while high settlement rates were being observed on newly deployed plates at the same stations (Fig. 4).

\section{Discussion}

The observed appearance and size succession of Cyanea sp. in the Niantic River was consistent with previous studies on Cyanea sp. at this site (Brewer $1989,1991)$. While, ephyrae were undoubtedly present in the water column before our sampling

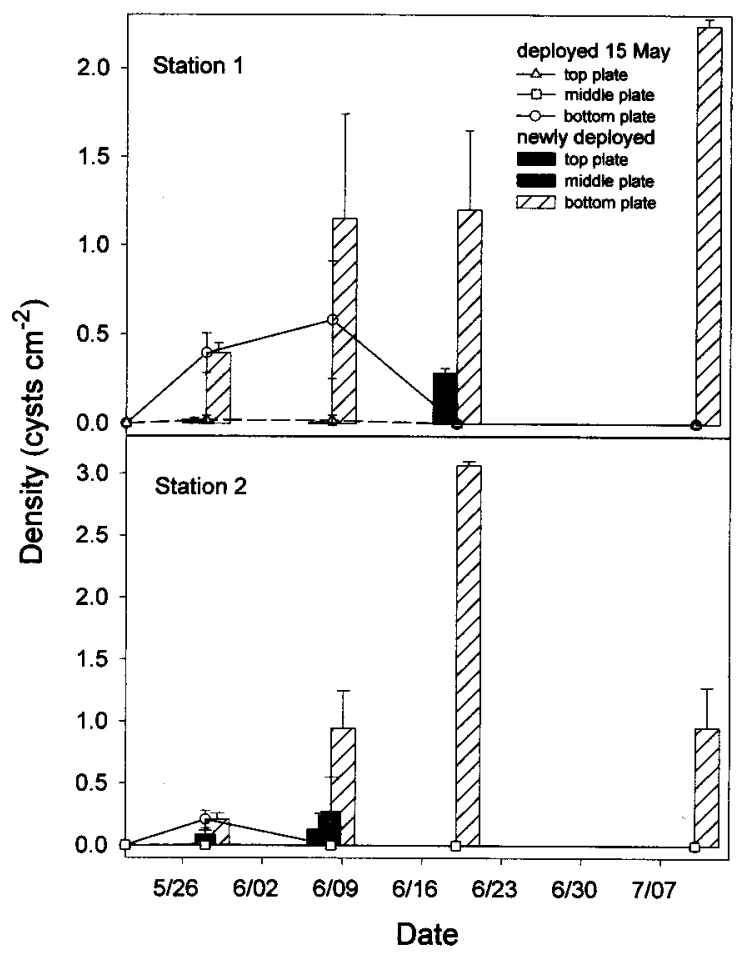

Fig. 4. Comparison of planulacysts abundance on plates newly deployed each week (bars) with those that were left in the water column since their deployment on May 15. Error bars represent standard errors.

started, we were able to observe the onset of the appearance of sexually mature medusae in the estuary (Fig. 3). The average bell diameter increased from $9.5 \mathrm{~mm}$ at the beginning of the study to 90.0 $\mathrm{mm}$ on June 25. After that, the average diameter decreased and only a few medusae were collected. The decline in average size is most likely due to the deterioration and mortality of the oldest and largest medusae in the population (Mills 1993) and is consistent with previously described patterns in the Niantic River estuary (Brewer 1989).

Temporally and spatially, the distribution of planulacysts on the settlement plates closely mirrored the distribution of adult medusae. Both the medusae and planulacysts were rarely observed outside of the northwest arm of the Niantic River estuary (Stations 1 and 2; Fig. 2). Marshall (1962) observed a similar retention of medusae upriver. This retention of the medusae in the upper estuary is most likely due to the hydrography. Drift studies indicate that there is a non-tidal drift upriver in deeper layers of the river (Marshall 1962). As a result, this Cyanea population has maintained itself in this restricted location for at least $40 \mathrm{yr}$. Peak settlement of planulae coincided with the peak abundance of adult medusae in the water column (Fig. 3). The closely linked spatial and temporal 
distributions of settled planulae and adult medusae suggests that released planulae are likely to have only a short residence time in the water column.

A clear settlement preference by planulae for near bottom surfaces was observed (Fig. 2), but the reason for this distribution is not clear. The vertical salinity gradient was weak, with the salinities at the top plates varying from 21.5 to $25 \mathrm{psu}$ while the bottom plates ranged from 23 to 27 psu. Known predators, including the nudibranch Coryphella sp. (Hernroth and Gröndahl 1985; Gröndahl and Hernroth 1987), also appeared to be absent.

Figure 4 can be used to interpret post-settlement population maintenance of planulae. Initially, planulae settled with high abundances on newly deployed plates. After two to three weeks, planulacysts disappeared from the plates. The disappearance coincided with large abundances of newly settled barnacles and ascidians. The high postsettlement decline of cysts on the settlement plates appears to be due to other benthic organisms out competing the cysts for space. A study examining the fate of settled Aurelia aurita planulae in Tokyo Bay, Japan observed similarly high disappearance rates, which appeared to coincide with the recruitment of other benthic organisms (Watanabe and Ishii 2001). Such a large decline in the population density of post-settled planulae might cause a population bottleneck in the life cycle of scyphozoa.

The high-stage specific mortality we observed for planulacysts raises the question: Under what conditions can newly settled planulae survive? It appears that the settled planulae must seek a refuge from the settlement of other benthic organisms for survival. This refuge could either be spatial or temporal. It is already known that planulae preferentially settle on the underside of objects (Brewer 1978) and that this orientation increases survival (Hernroth and Gröndahl 1983; Gröndahl and Hernroth 1987; Gröndahl 1988a; Watanabe and Ishii 2001). Presumably, polyps on the undersides of surfaces are protected from sedimentation. Settling in places where other organisms do not readily settle might be another strategy for survival, although this was not investigated as part of the present study. Scyphistomae are able to survive for weeks without food and recover quickly once conditions become favorable again (Costello personal communication). Therefore, areas of low food availability may provide additional spatial refuge.

The use of flat artificial settlement plates in our study and the study by Watanabe and Ishii (2001) may have produced higher than usual mortality by providing less spatial refuge than natural surfaces. While the plates used in this study have been shown to be very good surfaces for the settlement of other benthic invertebrates (Osman and Whi- tlatch 1995) and they were sufficient to support the settlement, metamorphosis, and growth of planulae in the laboratory (Brewer 1984; Colin unpublished data), they may not provide the refuge from other benthic organisms which are provided by the grooves and crevices of natural shells and rocks. Previous studies on scyphistomae in the Niantic River have found them inhabiting discarded oyster shells (Brewer 1991). The shells may provide protection to the scyphistomae that flat plates can not.

In addition to spatial refuges, survival of settled planulae may be increased if the planulae can avoid other settlers temporally. Accordingly, Watanabe and Ishii (2001) found much higher survival rates of scyphistomae which settled late in the season after the recruitment of other benthic organisms. Unfortunately, the fate of the planulae that settled late in the recruitment period was not documented in our Niantic River study.

It is clear that the distribution of the medusae directly determined the distribution of settled planulae. In turn, the post-settlement mortality of planulae was high due to the settlement of other benthic species. The survival of planulacysts and development into reproductive scyphistomae may act as a bottleneck in the life cycle of scyphozoans, strongly influencing the abundance and distribution of medusae. Thus, interannual differences in post-settlement mortality of planulacysts and polyps could have a large impact on the interannual abundance and distribution of medusae. Currently we know little about the longevity of the scyphistoma stage in nature. If polyp colonies are able to survive over several years, the interannual variability due to post-settlement mortality could be dampened considerably. Our conclusion remains that successful populations of scyphistomae will most likely be found in locations where medusae are seasonally abundant and where settled planulae can seek refuge from the settlement of other benthic organisms.

\section{ACKNOWLEDGMENTS}

We value and appreciate the comments of $\mathrm{J} . \mathbf{H}$. Costello, $\mathrm{H}$ G. Dam, B. K. Sullivan, P. Thor, and an anonymous reviewer. This study would not have been possible without the generous help from the residents around the Niantic River estuary who gave us access to their docks. We would also like to thank the Environmental Laboratory at Northeast Utilities Service Company for the use of laboratory space.

\section{Literäture Gited}

BÅmstedt, U., M. B. Martinussen, and S. Matsakis. 1994. Trophodynamics of the two scyphozoan jellyfishes, Aurelia aurita and Cyanea capillata, in western Norway. ICES Journal of Marine Sciences 51:369-382.

BEHRENDS, G. AND G. SCHNEIDER. 1995. Impact of Aurelia aurita medusae (Cnidaria, Scyphozoa) on the standing stock and 
community composition of mesoplankton in the Kiel Bight (western Baltic Sea). Marine Ecology Progress Series 127:39-45.

BREWER, R. 1978. Larval settlement behavior in the jellyfish $\mathbf{A u -}$ relia aurita. Estuaries 1:120-122.

BREWER, R. 1984. The influence of the orientation, roughness, and wettability of solid surfaces on the behavior and attachment of planulae of Cyanea. Biological Bulletin 166:11-21.

BREWER, R. 1989. The annual pattern of feeding, growth, and sexual reproduction in Cyanea (Cnidaria: Scyphozoa) in the Niantic River estuary, Connecticut. Biological Bulletin 176:272281.

BREWER, R. 1991. Morphological differences between, and reproductive isolation of two populations of the jellyfish Cyanea in Long Island Sound, USA. Hydrobiologia 216:471-477.

BREWER, R. AND J. FEINGOLD. 1991. The effect of temperature on the benthic stages of Cyanea (cnidaria: scyphozoa), and their seasonal distribution in the Niantic River, Connecticut. Journal of Experimental Marine Biology and Ecology 152:49-60.

CARGO, D. AND G. RABENOLD. 1980. Observations on the asexual reproduction activities of the sessile stage of the sea nettle, Chrysaora quinquecirrha (Scyphozoa). Estuaries 3:20-27.

CARGo, D. AND L. SchulTz. 1966. Notes on the biology of the sea nettle, Chrysaora quinquecirrha, in Chesapeake Bay. Chesapeake Science 7:95-100.

CARGo, D. AND L. SCHULTz. 1967. Further observations on the biology of the sea nettle and jellyfishes in Chesapeake Bay. Chesapeake Science 8:209-220.

Costello, J. H. AND S. P. Colin. 1994. Morphology, fluid motion and predation by the scyphomedusae Aurelia aurita. $\mathrm{Ma}$ rine Biology 121:327-334.

Costello, J. H. ANd S. P. Colin. 1995. Flow and feeding in scyphomedusae. Marine Biology 124:399-406.

CoWEN, J. AND E. HoudE. 1993. Relative predation potentials of scyphomedusae, ctenophores and planktivorous fish by ichthyoplankton in Chesapeake Bay. Marine Ecology Progress Series 95:55-65.

DOlmer, P. AND I. SVANe. 1993. Settlement patterns of the scyphozoan Cyanea capillata planula: Effects of established scyphistomae and water flow. Ophelia 38:117-126.

FANCETT, M. S. 1988. Diet and prey selection of scyphomedusae from Port Phillip Bay, Australia. Marine Biology 98:503-509.

Feigenbaum, D. AND M. Kelly. 1984. Changes in the lower Chesapeake Bay food chain in presence of the sea nettle Chrysaora quinquecirrha (scyphomedusa). Marine Ecology Progress Series 19: 39-47.

Ford, M., J. Costello, K. Heidelberg, and J. Purceli. 1997. Swimming and feeding by the scyphomedusa Chrysaora quinquecirrha. Marine Biology 129:355-362.

GRÖNDAHL, F. 1988a. Interactions between polyps of Aurelia aurita and planktonic larvae of scyphozoans: An experimental study. Marine Ecology Progress Series 45:87-93.

GröndAHL, F. 1988b. A comparative ecological study on the scyphozoans Aurelia aurita, Cyanea capillata and C. lamarckii in the Gullmar Fjord, western Sweden, 1982 to 1986. Marine Biology 97:541-550.

GRÖNDAHL, F. 1989. Evidence of gregarious settlement of planula larvae of the scyphozoan Aurelia aurita: An experimental study. Marine Ecology Progress Series 56:119-125.

GRÖNDAHL, F. AND L. HERNROTH. 1987. Release and growth of Cyanea capillata (L.) ephyrae in the Gullmar Fjord, western Sweden. Journal of Experimental Marine Biology Ecology 106:91101 .

HERnRoth, L. AND F. GRÓNDAHL. 1983. On the biology of Aurelia aurita (L.) 1. Release and growth of Aurelia aurita (L.) ephyrae in the Gullmar Fjord, western Sweden, 1982-83. Ophelia 22: 189-199.

HERNROTH, L. AND F. GRŌNDAHL. 1985. On the biology of Aurelia aurita: Major factors regulating the occurrence of ephyrae and the young medusae in the Gullmar Fjord, western Sweden. Bulletin Marine Science 37:567-576.

HunTley, M. E. AND L. A. HobSON. 1978. Medusa predation and plankton dynamics in a temperate fjord, British Columbia. Journal of Fisheries Research Board of Canada 35:257-261.

KEEN, S. 1987. Recruitment of Aurelia aurita larvae is positiondependent, and independent of conspecific density, within a settling surface. Marine Ecology Progress Series 38:151-160.

Kollmeyer, R. C. AND D. A. MCGill. 1972. A study of the Niantic River Estuary, Niantic, CT, by the Department of Physical and Ocean Science of the U.S. Coast Guard Academy Four reports: Physical, Chemical, Geological and Biological Studies. Mimeo. U.S. Coast Guard Academy, New London, Connecticut.

LOEB, M. 1972. Strobilation in the Chesapeake Bay sea nettle Chrysaora quinquecirrha. 1. The effects of environmental temperature changes on strobilation and growth. Jourmal of Experimental Zoology 180:279-292.

MARSHALL, N. 1962. Drift of medusae and their distribution in relation to the hydrography of the Niantic River, Connecticut. Limnology and Oceanography 7:268-269.

MrLLs, C. E. 1993. Natural mortality in NE Pacific coastal hydromedusae: Grazing predation, wound healing and senescence. Bulletin of Marine Sciences 53:194-203.

Möller, H. 1979. Significance of coelentrates in relation to other plankton organisms. Meeresforsh 27:1-18.

NUSCo (NoRTheast Utilities SeRvice Company). 1998. Winter flounder population studies, p. 149-224. In Monitoring the Marine Environment of Long Island Sound at Millstone $\mathrm{Nu}$ clear Power Station, Waterford, Connecticut. Annual Report 1998. Northeast Utilities Service Company, Waterford, Connecticut.

OSMAN, R. W. AND R. B. Whitlatch. 1995. The influence of resident adults on recruitment-A comparison to settlement. Journal of Experimental Marine Biology and Ecology 190:169-198.

PURCELL, J. E. 1992. Effects of predation by the scyphomedusan Chrysaora quinquecirrha on zooplankton populations in Chesapeake Bay, USA. Marine Ecology Progress Series 87:65-76.

PUrCELl, J. E. 1997. Pelagic cnidarians and ctenophores as predators: Selective predation, feeding rates and effects on prey selection. Annales de l'Institut Oceanographique 73:125-137.

Purcell, J. E. AND M. V. Sturdevant. 2001. Prey selection and dietary overlap among zooplanktivorous jellyfish and juvenile fishes in Prince William Sound, Alaska. Marine Ecology Progress Series 210:67-83.

Purcell, J. E., J. White, D. Nemazie, ANd D. Wright. 1999. Temperature, salinity and food effects on asexual reproduction of the scyphozoan, Chrysaora quinquecirrha. Marine Ecology Progress Series 180:187-196.

Sullnan, B., J. Garcla, And G. Klein-MacPhee. 1994. Prey selection by the scyphomedusan predator Aurelia aurita. Marine Biology 121:335-341.

SVANE, I. AND P. Dolmer. 1995. Perception of light at settlement: A comparative study of two invertebrate larvae, a scyphozoan planula and a simple ascidian tadpole. Journal of Experimental Marine Biology and Ecology 187:51-61.

Verity, P. G. AND V. SMETaCek. 1996. Organism life cycle, predation, and the structure of marine pelagic ecosystems. $M a$ rine Ecology Progress Series 130:277-293.

WATANABE, T. AND H. IsHII. 2001. In situ estimation of ephyrae liberated from polyps of Aurelia aurita using settling plates in Tokyo Bay. Hydrobiotogia 451:247-258.

\section{SOURCE OF UNPUBLISHED MATERIALS}

Costello, J. H. personal communication. Biology Department, Providence College, Providence, Rhode Island 02918.

Received for consideration, November 27, 2000 Accepted for publication, June 1, 2001 